\title{
Broken rice in feeds for laying Japanese quails
}

\section{Quirera de arroz em rações para codornas japonesas em postura}

\author{
Adriana Aparecida Pereira ${ }^{1}$; Wanderson Alves da Silva²; \\ Dorgival Morais de Lima Júnior ${ }^{1 *}$; Carolyny Batista Lima ${ }^{1}$; \\ Dirceu Neutzling Griep Júnior ${ }^{3}$; Geraldo Roberto Quintão Lana ${ }^{4}$; \\ Sandra Roselí Valerio Lana ${ }^{4}$ Leandro Pereira Oliveira ${ }^{5}$
}

\begin{abstract}
This study evaluated the effect, on productive performance and on egg quality, of replacing corn with broken rice in the feed of 64-148 day-old Japanese quails. The experiment was conducted in a randomized complete block design with five treatments consisting of five inclusion levels of broken rice $(0 \%, 25 \%, 50 \%, 75 \%$, and $100 \%)$ with eight replicates of eight birds each. No significant differences were observed in productive performance variables across treatments $(\mathrm{P}>0.05$, all). Regarding egg quality, no significant differences were observed in yolk percentage, specific gravity, or Haugh unit across treatments ( $\mathrm{P}>0.05$ for all parameters). However, yolk color index was negatively affected by dietary rice husk levels $\left(\mathrm{Y}=4.080-0.0293 \mathrm{X}, \mathrm{R}^{2}=98.56 \% ; \mathrm{P}<0.05\right)$. Thus, corn can be replaced with up to $100 \%$ broken rice in diets for laying Japanese quails without losses in productive performance or egg quality, but corn replacement with broken rice affects yolk color.
\end{abstract}

Key words: Alternative feedstuff. Rice by-product. Yolk color.

\section{Resumo}

Objetivou-se avaliar a substituição do milho pela quirera de arroz, em rações de codornas japonesas em postura sobre o desempenho zootécnico e a qualidade de ovos no período de 64 a 148 dias de idade. $\mathrm{O}$ experimento foi conduzido em um delineamento de blocos casualizados com cinco tratamentos, que consistiram na inclusão de cinco níveis $(0,25,50,75$ e 100\%) de quirera de arroz em substituição ao milho nas rações, com oito repetições de oito aves cada. Não foram verificadas diferenças significativas $(\mathrm{P}>0,05)$ para as características de desempenho das aves. Para as características de qualidade de ovos, não foram observadas diferenças significativas $(\mathrm{P}>0,05)$ sobre as variáveis percentagens de gema, gravidade específica e unidade Haugh. Entretanto, a coloração da gema sofreu influencia $(\mathrm{P}<0,05)$ pelos dos níveis de inclusão de quirera de arroz, verificando efeito linear negativo ( $\mathrm{Y}=4,080$ - 0,0293X; $\mathrm{R}^{2}=98,56 \%$ ) com o aumento da inclusão da quirera. É possível substituir o milho em até $100 \%$ pela quirera de arroz em rações para codornas japonesas em postura, sem que haja prejuízos no desempenho

\footnotetext{
${ }^{1}$ Profs. Adjuntos, Universidade Federal de Alagoas, UFAL, Campus Arapiraca, Arapiraca, AL, Brasil. E-mail: adri_zoo@hotmail. com; juniorzootec@yahoo.com.br; cblzte@hotmail.com

2 Discente do Programa de Pós-Graduação em Ciência Animal e Pastagem, Universidade Federal Rural de Pernambuco, UFRPE, Unidade Acadêmica de Garanhuns, UAG, Garanhuns, PE, Brasil. E-mail: wandersonzoo@live.com

${ }_{3}$ Discente do Programa de Pós-graduação em Zootecnia, Universidade Federal de Sergipe, UFS, São Cristovão, SE, Brasil. E-mail: dirceugriep@hotmail.com

${ }^{4}$ Profs. Associados, UFAL, Centro de Ciências Agrárias, CECA, Rio Largo, AL, Brasil. E-mail: glana@bol.com.br; svlana@bol. com.br

5 Discente do Programa de Doutorado Integrado em Zootecnia, Universidade Federal da Paraíba, UFPB, Areia, PB, Brasil. E-mail: glana@bol.com.br

* Author for correspondence
} 
produtivo das aves e na qualidade dos ovos. Porém, a substituição do milho por quirera causa diminuição da coloração da gema.

Palavras-chave: Alimento alternativo. Coloração da gema. Subproduto do arroz.

In recent years, quail farming became a quick source of meat and eggs because of the short bird production cycles (35-42 days), high egg productivity (300 eggs year-1 on average), rapid bird growth, small space demand, low investment, and quick return on capital (ALBINO; BARRETO, 2003). Currently, Brazil is the fifth largest quail meat producer and second largest quail egg producer. This position is maintained due to a increase in production in several regions of the country, increase in automated production facilities, and value aggregation through several types of egg and quail carcass commercialization (SILVA et al., 2012).

Feed costs account for approximately 75\% of production costs in quail farming. In regions where corn and soybean production do not meet demand, the best alternative is to seek industry or agribusiness processing outputs that can replace part or all of these ingredients, as an option to reduce production costs without compromising breeding performance and economic viability (BARRETO et al., 2010; ETUK et al., 2012). Rice is the second most produced cereal worldwide, after corn, but its use in poultry diets is unusual, due to its higher cost compared to corn. However, one of the by-products of rice milling, broken rice, has a much lower market value, making it possible to use it in animal feeding when its price is lower than that of corn. Broken rice is a high-energy food that provides $3279 \mathrm{kcal} \mathrm{kg-1}$ of metabolizable dry matter, and has a crude protein content of approximately 8.5\% (CANCHERINI et al., 2008; NERY et al., 2010; ROSTAGNO et al., 2011). These characteristics enable its use in quail diets as a replacement for corn (CARDOSO et al., 2011; QUEVEDO FILHO et al., 2013).

This study evaluated the effect of replacing corn with broken rice on the productive performance and on the egg quality of 64-148 day-old Japanese quails. The experiment was conducted at the Poultry
Division of the Universidade Federal de Alagoas (UFAL), Arapiraca Campus, Arapiraca, AL, Brazil, from April to July 2013, with a duration of 84 days. A total of 320 one day-old female quails (Coturnix japonica), were acquired from Granja Fujikura ${ }^{\circledR}$, (Suzano, SP, Brazil) for the study. Quails were raised in rabbit cages, adapted with thermostatcontrolled heat lamps, until 21 days of age; they were then transferred to galvanized wire laying cages ( $1.0 \mathrm{~m}$ long x $0.33 \mathrm{~m}$ wide x $0.25 \mathrm{~m}$ high), where they remained throughout the experimental period. Quails were fed raising and restocking feeds, from the day they were received until laying their first egg, at approximately 40 days of age, when they were switched to laying feed (ROSTAGNO et al., 2011). At 64 days of age, quails (average weight: $173 \pm 10 \mathrm{~g}$ [mean $\pm \mathrm{SD}$ ]) were distributed, in a randomized block design, in 40 cages with eight birds each, stacked in 5 rows, with passive ventilation, where they remained for four cycles of 21 days each. Each cage was divided into three 0.33 $\mathrm{m}$ divisions, with a chute-type feeder traversing the cage length, a nipple drinker on the top of the cage, and an excreta catcher under the cage. The feeders were supplied with the experimental feed twice daily, at 07:00 am and 04:30 pm. The lighting program was 17 hours of light / 7 hours of darkness, with $12 \mathrm{~h}$ of natural light and $5 \mathrm{~h}$ of artificial light, controlled by a timer. The minimum and maximum values for ambient temperature and relative humidity inside the aviary were $23.8^{\circ} \mathrm{C}$ and 30.95 ${ }^{\circ} \mathrm{C}$; and $52.61 \%$, and $82.59 \%$, respectively, recorded daily during the experimental period with a digital thermo-hygrometer positioned at the birds' height.

The treatments consisted of $0 \%, 25 \%, 50 \%$, $75 \%$, and $100 \%$ substitution of broken rice for corn in quail feeds. Broken rice, sourced from mills of the state of Alagoas (Indústrias Reunidas Coringa Ltda, Arapiraca, AL, Brazil), was chopped into 
a $1 \mathrm{~mm}$ sieve, to avoid particle selection by the quails. Five isonitrogenous and isocaloric diets, with the different proportions of corn and broken rice, were formulated using Super Crac 5.0 software
(CPT softwares LTDA, Viçosa, Minas Gerais, Brazil), following the chemical composition and nutritional requirements for laying Japanese quails recommended by Rostagno et al. (2011) (Table 1).

Table 1. Formulation and chemical composition of experimental diets.

\begin{tabular}{|c|c|c|c|c|c|}
\hline \multirow{2}{*}{ Ingredient } & \multicolumn{5}{|c|}{ Broken rice inclusion levels (\%) } \\
\hline & 0 & 25 & 50 & 75 & 100 \\
\hline Corn & 49.902 & 39.074 & 24.94 & 12.471 & - \\
\hline Soybean meal & 39.44 & 37.425 & 38.936 & 38.652 & 38.362 \\
\hline Broken rice & - & 12.475 & 24.94 & 37.415 & 49.9 \\
\hline Dicalcium phosphate & 0.974 & 1.006 & 1.035 & 1.066 & 1.097 \\
\hline Limestone & 6.646 & 6.626 & 6.606 & 6.586 & 6.566 \\
\hline Soybean oil & 2.116 & 2.436 & 2.679 & 2.945 & 3.211 \\
\hline Salt & 0.31 & 0.313 & 0.316 & 0.32 & 0.323 \\
\hline DL-methionine & 0.386 & 0.33 & 0.324 & 0.32 & 0.316 \\
\hline Laying premix vit. ${ }^{1}$ & 0.1 & 0.1 & 0.1 & 0.1 & 0.1 \\
\hline Bird premix min. ${ }^{2}$ & 0.05 & 0.05 & 0.05 & 0.05 & 0.05 \\
\hline Choline chloride & 0.040 & 0.040 & 0.040 & 0.040 & 0.040 \\
\hline L-lysine $\mathrm{HCl}$ & 0.022 & 0.026 & 0.021 & 0.022 & 0.022 \\
\hline Antioxidantt & 0.010 & 0.010 & 0.010 & 0.010 & 0.010 \\
\hline TOTAL & 100 & 100 & 100 & 100 & 100 \\
\hline \multicolumn{6}{|c|}{ Calculated Composition } \\
\hline Metabolizable energy $\left(\mathrm{kcal} \mathrm{kg}^{-1}\right)$ & 2.8 & 2.8 & 2.8 & 2.8 & 2.8 \\
\hline Crude protein $(\%)$ & 22.323 & 22.202 & 22.207 & 22.152 & 22.096 \\
\hline Crude fiber $(\%)$ & 3.063 & 2.863 & 2.674 & 2.478 & 2.282 \\
\hline Fat $(\%)$ & 5.378 & 5.17 & 4.889 & 4.63 & 4.369 \\
\hline Total phosphorus (\%) & 0.553 & 0.5471 & 0.541 & 0.535 & 0.529 \\
\hline Calcium (\%) & 2.922 & 2.922 & 2.922 & 2.922 & 2.922 \\
\hline Sodium $(\%)$ & 0.146 & 0.146 & 0.146 & 0.146 & 0.146 \\
\hline Total lysine $(\%)$ & 1.233 & 1.233 & 1.233 & 1.233 & 1.233 \\
\hline Total methionine $(\%)$ & 0.699 & 0.647 & 0.646 & 0.647 & 0.648 \\
\hline Total Met + Cist (\%) & 1.052 & 0.999 & 0.999 & 0.999 & 0.999 \\
\hline Total tryptophan $(\%)$ & 0.278 & 0.282 & 0.287 & 0.292 & 0.296 \\
\hline Linoleic acid (\%) & 2.376 & 2.357 & 2.298 & 2.251 & 2.204 \\
\hline Total arginine $(\%)$ & 1.502 & 1.418 & 1.542 & 1.561 & 1.58 \\
\hline Total phenylalanine $(\%)$ & 1.115 & 1.109 & 1.108 & 1.104 & 1.1 \\
\hline Total phenyl. + tyr. (\%) & 1.896 & 1.898 & 1.91 & 1.916 & 1.922 \\
\hline Total histidine $(\%)$ & 0.588 & 0.578 & 0.572 & 0.563 & 0.555 \\
\hline Total isoleucine $(\%)$ & 0.97 & 0.973 & 0.98 & 0.984 & 0.987 \\
\hline Total leucine (\%) & 1.869 & 1.825 & 1.788 & 1.747 & 1.706 \\
\hline Total threonine (\%) & 0.861 & 0.85 & 0.842 & 0.832 & 0.822 \\
\hline Total valine $(\%)$ & 1.056 & 1.058 & 1.065 & 1.0687 & 1.072 \\
\hline
\end{tabular}

${ }^{1}$ Enrichment per kg of feed: folic acid, $1000 \mathrm{mg}$; pantothenic acid, $1562 \mathrm{mg}$; biotin, $100 \mu \mathrm{g}$; niacin, $3980 \mathrm{mg}$; vitamin D3, 7000000 UI; vitamin E, $2000 \mathrm{mg}$; vitamin B12, 3000 g; vitamin B2, $4000 \mathrm{mg}$; vitamin B1, $3000 \mathrm{mg}$; vitamin D3, 2100000 UI; vitamin K3, $2000 \mathrm{mg}$; Se, $200 \mathrm{mg}$; and antioxidant, $100000 \mathrm{mg}$.

${ }^{2}$ Enrichment per kg of feed: Zn, $70000 \mathrm{mg}$ (min.); I, $1500 \mathrm{mg}$ (min.); Cu, $8500 \mathrm{mg}$ (min.); Mn, $75000 \mathrm{mg}$ (min.); Fe, $50000 \mathrm{mg}$ (min.); and Co, 200mg. 
Laying quails were distributed in a randomized complete block design ( 8 birds $\mathrm{x} 5$ treatments) with 8 replicates ( 1 replicate $=1$ cage) per treatment, to account for the effect of cage placement. The following productivity performance variables were evaluated over four 21-day periods: feed intake (g.bird-1.day-1), laying percentage (\%), average egg weight $(\mathrm{g})$, feed conversion ratio per egg mass ( $\mathrm{kg}$ of feed.kg eggs-1), and feed conversion ratio per dozen eggs (kg of feed.dozen eggs-1). The following egg quality characteristics were determined: egg weight $(\mathrm{g})$, yolk percentage $(\%)$, albumen percentage $(\%)$, shell percentage (\%), specific gravity (g cm-3), Haugh unit, and yolk color score.

Feed intake (g.bird-1.day-1) was recorded every 21 days: the feed for each cage was weighed and placed into plastic buckets with a $3-\mathrm{kg}$ capacity; on the 21st day of each cycle, food leftovers from each unit were returned to the bucket, weighed, and the feed intake of the period was determined; average feed consumption was corrected for dead birds. Eggs were collected daily at 07:00 am for the determination of total egg production, whereas laying percentage was calculated per cage. Feed conversion ratio was calculated by dividing the average daily feed intake by the average daily production in dozen eggs and in kilograms. Average egg weight (and also yolk and shell weights, below) was determined with an accuracy of $0.01 \mathrm{~g}$ with a digital analytic scale (Model EEQ9003E, DS Diagnóstica, São Paulo, Brazil) from a sample of three eggs/plot/day collected in the last two days of each period.

Egg quality characteristics were determined from the three most homogeneous eggs selected from each cage. Specific gravity was measured immediately after weighing the eggs: intact eggs were immersed in $\mathrm{NaCl}$ solutions of densities ranging from 1.005 g.cm-3 to 1.100 g.cm-3 at 0.005 g.cm-3 intervals (measured with a densitometer Incoterm ${ }^{\circledR}$, Porto Alegre, RS, Brazil) and the eggs were classified according to their specific gravity when they floated. Haugh unit was determined by the formula $\mathrm{HU}=100 \times \log (\mathrm{H}-1.7 \mathrm{~W} 0.37+7.6)$, where $\mathrm{H}=$ albumen height (measured on a flat glass surface with a micrometer), and $\mathrm{W}=$ egg weight. Yolk weight was divided by egg weight to determine yolk percentage. Yolk color was determined by visual comparison with a colorimetric array (DSM Nutritional Products, Heerlen, The Netherlands). To determine shell percentage of egg weight, eggshells were washed with tap water, dried in the shade at room temperature for $48 \mathrm{~h}$, and weighed to the nearest $0.01 \mathrm{~g}$. Albumen percentage was determined by the formula $100-(\%$ yolk $+\%$ shell $)$.

Data for each condition were compared using analysis of variance (ANOVA) and, in case of significant difference $(\mathrm{P}<0.05)$, regression analysis was used to determine the best dietary level of broken rice. All analyses were performed using SAS software (2000).

Table 2 shows the results for feed intake, laying percentage, average egg weight, and feed conversion ratio per dozen eggs and per egg mass. All productive performance variables were similar across treatments $(\mathrm{P}>0.05)$, in line with the observation that, in general, rice by-products have been added in varying levels to poultry diets with satisfactory performance results (BRUM JUNIOR et al., 2007; QUEVEDO FILHO et al., 2013; FARIAS et al., 2014; GOPINGER et al., 2014). Cardoso et al. (2011) and Freitas et al. (2013) also found no effect of broken rice on feed intake in quails. The difference in metabolizable energy between broken rice and corn for poultry (NARVÁEZ-SOLARTE et al., 2012) was corrected, in this study, in with the addition of oil to the feed, a method that is supported by the studies of Junqueira et al. (2009) and Rostagno et al. (2011). Egg production was also not affected by replacing corn with broken rice in quail diets: mean values of laying percentage and egg weight across treatments were $90.35 \%$ and $12.14 \mathrm{~g}$, respectively. This indicates that broken rice diets met the nutritional demands of laying quails. Feed conversion ratios per egg mass (mean $2.39 \mathrm{~kg}$ feed.kg eggs-1) and per dozen eggs (mean $0.35 \mathrm{~kg}$ feed.dozen eggs-1) were also similar across diets. 
Table 2. Mean values of feed intake, laying percentage, egg weight, and feed conversion in Japanese quails fed different broken rice levels.

\begin{tabular}{|c|c|c|c|c|c|c|c|}
\hline \multirow{2}{*}{ Variable } & \multicolumn{5}{|c|}{ Broken rice inclusion level (\%) } & \multirow{2}{*}{$\mathrm{P}$} & \multirow{2}{*}{$\begin{array}{l}\mathrm{CV} \\
(\%)\end{array}$} \\
\hline & 0 & 25 & 50 & 75 & 100 & & \\
\hline FI $\left(\mathrm{g} \mathrm{bird}^{-1}\right.$ day $\left.^{-1}\right)$ & 25.95 & 26.65 & 25.01 & 25.73 & 25.98 & 0.0505 & 5.84 \\
\hline$\%$ LAY. & 89.8 & 93.02 & 89.21 & 88.63 & 90.85 & 0.7534 & 8.15 \\
\hline EW (g) & 12.15 & 12.09 & 12.1 & 12.38 & 11.97 & 0.4213 & 3.42 \\
\hline FC $\left(\right.$ kg dozen eggs $\left.{ }^{-1}\right)$ & 0.35 & 0.34 & 0.34 & 0.36 & 0.34 & 0.8586 & 9.87 \\
\hline $\mathrm{FC}\left(\mathrm{kg} \mathrm{kg} \mathrm{eggs}^{-1}\right)$ & 2.39 & 2.38 & 2.35 & 2.45 & 2.39 & 0.9399 & 10.16 \\
\hline
\end{tabular}

$\mathrm{FI}=$ feed intake; $\%$ LAY. = laying percentage $\mathrm{EW}=$ egg weight $\mathrm{FC}=$ feed conversion; $\mathrm{CV}=$ coefficient of variation.

Mean yolk, albumen, and shell percentages were $29.0 \%, 62.9 \%$, and $8.1 \%$, respectively, and were not significantly affected by the inclusion of broken rice in quail diets $(\mathrm{P}>0.05$, all; Table 3). Similar values for yolk, albumen, and eggshell percentages were reported by Santos et al. (2014) in quails fed broken rice. Mean egg specific gravity $\left(1.08 \mathrm{~g} \mathrm{~cm}^{-3}\right)$ was within the desired range and was not significantly different across inclusion levels $(\mathrm{P}>0.05)$. Similar results were observed in chicken, when corn was totally replaced by broken rice (RAO, 2000). However, mean Haugh unit (78.04) was significantly different across treatments $(\mathrm{P}<$ 0.05), although still at levels considered of excellent quality for egg protein (USDA, 2000).

Table 3. Mean values of yolk percentage, shell percentage, albumen percentage, egg specific gravity, and Haugh unit in eggs from Japanese quails fed different broken rice levels.

\begin{tabular}{|c|c|c|c|c|c|c|c|}
\hline \multirow{2}{*}{ Variable } & \multicolumn{5}{|c|}{ Broken rice inclusion levels (\%) } & \multirow{2}{*}{$P$ value } & \multirow{2}{*}{$\begin{array}{l}\mathrm{CV} \\
(\%)\end{array}$} \\
\hline & 0 & 25 & 50 & 75 & 100 & & \\
\hline$\%$ yolk & 29.35 & 28.90 & 28.56 & 28.97 & 29.02 & 0.873 & 4.84 \\
\hline$\%$ albumen & 62.84 & 63.07 & 63.35 & 62.90 & 62.55 & 0.8471 & 1.86 \\
\hline$\%$ eggshell & 8.04 & 8.15 & 8.1 & 8.06 & 7.98 & 0.6463 & 3.01 \\
\hline $\mathrm{SG}\left(\mathrm{g} \mathrm{cm}^{-3}\right)$ & 1.075 & 1.074 & 1.075 & 1.081 & 1.075 & 0.6279 & 0.91 \\
\hline $\mathrm{HU}$ & 77.95 & 79.15 & 78.61 & 78.32 & 76.18 & $0.0195 *$ & 2.63 \\
\hline
\end{tabular}

$\mathrm{SG}=$ specific gravity; $\mathrm{HU}=$ Haugh unit; $\mathrm{CV}=$ coefficient of variation; $* \mathrm{P}<0.05$.

Yolk color index was negatively affected by dietary broken rice levels ( $\mathrm{Y}=4.080-0.0293 \mathrm{X}, \mathrm{R}^{2}$ $=98.56 \%, \mathrm{P}<0.05$; Figure 1$)$. A similar effect on yolk color of the use of pearl millet in quail diets was reported by Garcia et al. (2012). This is likely due to the lower content of xanthophyll pigments in rice compared to corn (BRUM JUNIOR et al., 2007). In commercial hen eggs, richer-colored yolks are desirable, and that characteristic depends exclusively on the feed, because even though they are not able to synthesize them, hens can absorb between $20 \%$ and $60 \%$ of the feed pigments (MOURA et al., 2011). However, because quail eggs are generally eaten boiled or preserved in brines, egg yolk color is an attribute of little relevance to the consumer, and thus of secondary economic importance (MOURA et al., 2010; GOPINGER et al., 2014). Therefore, it is likely that broken rice can be included in quail diets without any commercial effects related to 
yolk color. Otherwise, the economic and market viability of including natural or artificial pigments in quail diets with high dietary broken rice levels to improve yolk color may be evaluated.

Figure 1. Relationship between inclusion level and yolk color index in eggs from Japanese quails fed broken rice (Y $=4.078-0.0293 \mathrm{X} ; \mathrm{R}^{2}=0.98$ ).

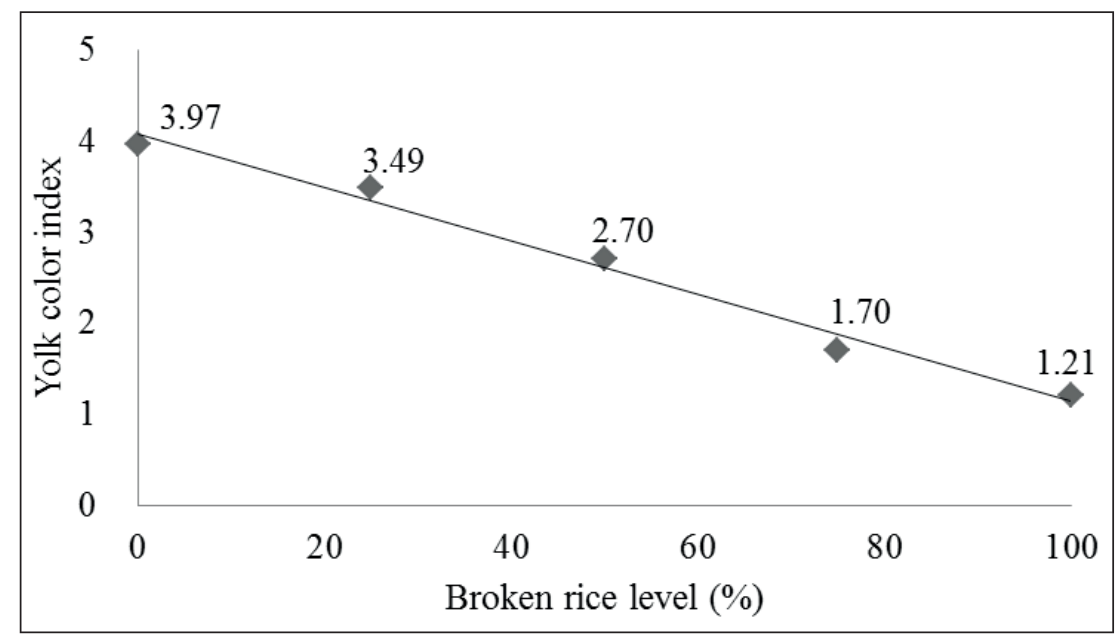

Corn can be replaced with up to $100 \%$ broken rice in diets for laying Japanese quails without loss in productive performance or egg quality. Yolk color index decreased with increasing dietary broken rice levels, but contrary to what is observed for hen eggs, the impact of this effect on quail egg commercial value should be minimal or nonexistent.

\section{References}

ALBINO, L. F. T.; BARRETO, S. L. T. Codornas: criação de codornas para produção de ovos e carne. Viçosa, MG: Aprenda Fácil. 2003. 290 p.

BARRETO, S. L. T.; MOURA, W. C. O.; REIS, R. S.; HOSODA, L. R.; MAIA, G. V. C.; PENA, G. M. Soja integral processada em dietas para codornas japonesas em postura. Revista Brasileira de Zootecnia, ViçosaMG, v. 39, n. 9, p. 1978-1983, 2010.

BRUM JUNIOR, B. S.; ZANELLA, I.; TOLEDO, G. S. P.; XAVIER, E. G.; VIEIRA, T. A.; GONÇALVES, E. C.; BRUM, H.; OLIVEIRA, J. L. S. Dietas para frangos de corte contendo quirera de arroz. Ciência Rural, Santa Maria, v. 37, n. 5, p. 1423-1429, 2007.
CANCHERINI, L. C.; DUARTE, K. F.; JUNQUEIRA, O. M.; FILARDI, R.; LAURENTIZ, A. C.; ARAÚJO, L. F. Desempenho e rendimento de carcaça de frangos de corte alimentados com dietas contendo subprodutos do arroz formuladas com base nos conceitos de proteína bruta e ideal. Revista Brasileira de Zootecnia, Viçosa, MG, v. 37, n. 4, p. 616-623, 2008.

CARDOSO, D.; SALEM, A. Z. M.; PROVENZA, F. D.; ROJO, R.; CAMACHO, L. M.; SATTERLEE, D. G. Cereal type in diet and housing system influences on growth performance and carcass yield in two Japanese quail genotypes. Animal Feed Science and Technology, Madri, v. 163, n. 3, p. 52-58, 2011.

ETUK, E. B.; IFEDUBA, A. V.; OKATA, U. E.; CHIAKA, I.; IFEANYI, C.; OKEUDO, N. J.; ESONU, B. O.; UDEDIBIE, A. B. I.; MOREKI, J. C. Nutrient Composition and Feeding Value of Sorghum for Livestock and Poultry: a Review. Journal of Animal Science Advances, Shabestar, v. 2, n. 6, p. 510-524, 2012.

FARIAS, N. N. P.; FREITAS, E. R.; XAVIER, R. P. S.; BRAZ, N. M.; TAVARES, T. C. L.; FIGUEIREDO, C. W. S.; FERNANDES, D. R.; NASCIMENTO, G. A. J. Farelo integral de arroz parboilizado submetido a armazenamento prolongado para alimentação de codornas de corte. Pesquisa Agropecuária Brasileira, Brasília, v. 49, n. 6, p. 407-415, 2014. 
FREITAS, E. R.; QUEVEDO FILHO, I. B.; WATANABE, P. H.; FILGUEIRA, T. M. B.; CRUZ, C. E. B.; TAVARES, T. C. L. Parboiled rice bran in Japanese quail diets at growing phase and residual effect at laying period. Ciência e Agrotecnologia, Lavras, v. 37, n. 4, p. 350-358, 2013.

GARCIA, A. F. Q. M.; MURAKAMI, A. E.; MASSUDA, E. M.; URGNANI, F. J.; POTENÇA, A.; DUARTE, C. R. A.; EYNG, C. Milheto na alimentação de codornas japonesas. Revista Brasileira de Saúde e Produção Animal, Salvador, v. 13, n. 1, p. 150-159, 2012.

GOPINGER, E.; MORAES, P. O.; CATALAN, A. A. S.; XAVIER, E. G.; CASTRO, M. L.; SCHAFHAUSER JUNIOR, J. Whole rice in japanese quails' diet. Acta Scientiarum. Animal Sciences, Maringá, v. 36, n. 4, p. 363-367, 2014.

JUNQUEIRA, O. M.; DUARTE, K. F.; CANCHERINI, L. C.; ARAÚJO, L. F.; OLIVEIRA, M. C.; GARCIA, E. A. Composição química, valores de energia metabolizável e aminoácidos digestíveis de subprodutos do arroz para frangos de corte. Ciência Rural, Santa Maria, v. 39, n. 8, p. 2497-2503, 2009.

MOURA, A. M. A.; FONSECA, J. B.; RABELO, C. B.; TAKATA, F. N.; OLIVEIRA, N. T. E. Desempenho e qualidade do ovo de codornas japonesas alimentadas com rações contendo sorgo. Revista Brasileira de Zootecnia, Viçosa, MG, v. 39, n. 12, p. 2697-2702, 2010.

MOURA, A. M. A.; TAKATA, F. N.; NASCIMENTO, G. R.; SILVA, A. F.; MELO, T. V.; CECON, P. R. Pigmentantes naturais em rações à base de sorgo para codornas japonesas em postura. Revista Brasileira de Zootecnia, Viçosa, MG, v. 40, n. 11, p. 2443-2449, 2011.

NARVÁEZ-SOLARTE, W.; NARANJO, J. P. T.; MURILLO, C. E. G. Digestibilidad de materias primas energéticas extrusadas en la alimentación de codornices (Coturnix coturnix japonicus). Biosalud, Manizales, v. 11, n. 2, p. 59-69, 2012.
NERY, V. L. H.; SOARES, R. T. R. N.; CHIQUIERI, J. Desempenho e características de carcaça de suínos em terminação alimentados com rações contendo subprodutos de arroz. Zootecnia Tropical, Maracay, v. 28, n. 1, p. 43-49, 2010.

QUEVEDO FILHO, I. B.; FREITAS, E. R.; FILGUEIRA, T. M. B.; NASCIMENTO, G. A. J.; BRAZ, N. M.; FERNANDES, D. R.; WATANABE, P. H. Parboiled rice whole bran in laying diets for Japanese quais. Pesquisa Agropecuária Brasileira, Brasília, v. 48, n. 6, p. 582-588, 2013.

RAO, S. V.; REDDY, M. R.; PRARHARAI, N. K.; SUNDER, G. S. Laying performance of broiler breeder chickens fed various millets or broken rice as a source of energy at a constant nutrient intake. Tropical Animal Health and Production, Midlothian, v. 32, n. 5, p. 329338,2000 .

ROSTAGNO, H. S.; ALBINO, L. F. T.; DONZELE, J. L.; GOMES, P. C.; OLIVEIRA, R. F.; LOPES, D. C.; FERREIRA, A. S.; BARRETO, S. L. T.; EUCLIDES, R. F. Tabelas brasileiras para aves e suínos: composição de alimentos e exigências nutricionais. 3. ed. Viçosa, MG: UFV, 2011. 252 p.

SANTOS, G. C.; GARCIA, E. A.; VIEIRA FILHO, J. A.; MOLINO, A. B.; PELÍCIA, K.; BERTO, D. A.; MURAKAMI, E. S. F.; MONTENEGRO, A. T. Feed type for induced molting of commercial layer hens. Revista Brasileira de Zootecnia, Viçosa, MG, v. 43, n. 3, p. 146-150, 2014.

SILVA, J. H. V.; JORDÃO FILHO, J.; COSTA, F. G. P.; LACERDA, P. B.; VARGAS, D. G. V.; LIMA, M. R. Exigências nutricionais de codornas. Revista Brasileira de Saúde e Produção Animal, Salvador, v. 13, n. 3, p. 775-790, 2012.

UNITED STATES DEPARTMENT OF AGRICULTURE - USDA. Egg-Grading Manual. Washington: Agricultural Marketing Service. Agricultural Handbook. 2000. n. 75. Available at: $<$ http://www.ams.usda.gov/AMSv1.0/getfil edDocName $=$ STELDEV3004502 $>$. Accessed at: $12 \mathrm{dec}$. 2014. 
